\title{
Body Architecture of Holstein Friesian and Black Frison Biotypes Used in South Chilean Dairy Farms
}

\author{
Arquitectura Corporal de Biotipos Bovinos Holstein Friesian y \\ Overo Negro Utilizados en Predios Lecheros del Sur de Chile
}

De la Barra, R. ${ }^{\text {; }}$ Carvajal, A. M. ${ }^{1}$; Martínez, M. E. ${ }^{2}$ \& Morales, R. ${ }^{1}$

\begin{abstract}
DE LA BARRA, R.; CARVAJAL, A. M.; MARTÍNEZ, M. E. \& MORALES, R. Body architecture of Holstein Friesian and Black Frison biotypes used in South Chilean dairy farms. Int. J. Morphol., 37(4):1444-1449, 2019.

SUMMARY: The objective of the present work was to characterize the morphostructural architecture of bovine biotypes that are mostly used in milk production in southern Chile. Measurements were carried out in 26 dairy farms located in the provinces of Osorno and Ranco, in Los Lagos and Los Ríos regions, respectively. In each farm, four animals were randomly selected from the herd; 104 four year-old cows were measured. Cows were classified into four biotypes: Holstein Friesian (HD), Overo Negro (OD), hybrid Friesian Holstein (HM) and hybrid Overo Negro (OM), according to the opinion of the owner or administrator. Nine body measurements were taken: head length (HL), head width (HW), withers height (WH), rump height (RH), bicostal diameter (BD), longitudinal diameter (LD), rump width (RW), rump length (RL) and dorso-sternal diameter (DED). Data were analyzed by principal component analysis (PCA) and the Fisher LSD test. The evaluated animals seem to converge around a basic architecture derived from cultural selection patterns regardless of the racial biotype. This architecture could be typical of grazing systems or be influenced by aspects of selection additional to those directly related to production. The data suggest that the body architecture of the dairy cattle evaluated would respond to selection patterns more than to racial biotypes. It was also seen that measures such as DED, RW and LD have a greater incidence than the other variables within the observed common selection patterns. Finally, within the evaluated animal population, two selection patterns coexist, one represented by small size body architecture and another one that, although despite its larger dimensions, also represents a small dairy animal in comparison to the sizes reported for Holstein Friesian breed in other areas.
\end{abstract}

KEY WORDS: Morphology; Cattle; Population characteristics; Ethnology.

\section{INTRODUCTION}

The body architecture of an animal biotype varies over time in animal populations, and is the result of various factors that influence the gene pool that predominates in a population and the expression of the characteristics that encode these genes (Salinas, 2017). On the one hand, there is a founding effect generated by the genetic constitution that came in the first lineages when the population was introduced, and where the founder gene pool is not representative of the original genetic diversity. On the other hand, there are hybridation phenomena between racial populations, as well as inbreeding (Notter, 1999; Vergara, 2002; Mc Parland et al., 2007), which alter the frequency of certain genes. In turn, selection (both natural and anthropic) also alters the composition of the genetic pool. The aspects related to the founding effect, hybridization, inbreeding and selection alter the animal body architecture by privileging certain genetic combinations in offspring and closing others (Chirinos, 2011; Zhicay Orellana, 2016).

\footnotetext{
${ }^{1}$ Instituto de Investigaciones Agropecuarias, INIA Remehue, Chile.

${ }^{2}$ Instituto de Investigaciones Agropecuarias, INIA Butalcura, Chile.
}

The history of bovine cattle in the south of Chile indicates that the first bovines introduced to this territory had an Iberian origin; they were successfully adapted having great resistance and hardiness, but with meager yields in meat and milk production (Matthei, 1939). For this reason, it was carried out an absorption process through crosses with improved bovine breeds that were introduced for that purpose. Thus, from the middle of the nineteenth century, Shortorn (c.1843), Holstein Friesian (c.1895), Overo Negro and Overo Colorado (Correa, 1938; Matthei; Corporación de Fomento de la Producción, 1962) bulls were mainly imported.

Currently, in Los Lagos and Los Ríos regions, the predominant bovine breeds are Overo Negro (also known as European Black Friesian) and Holstein Friesian (Peralta, 1991; Campos et al., 2012) representing more than eighty percent of the total of dairy cow biotypes in this territory 
(Anrique et al., 2004). In this sense, both breeds are an essential part of the metapopulation of genes that supports the production of milk (and also meat) in southern Chile grazing systems.

The Overo Negro is a bovine population of long adaptation to the country, with a discontinuous genetic flow since the import of genetics of this breed was mostly replaced with others. In contrast, the Holstein Friesian breed, although it is also a long adaptation population, has maintained a constant introduction of improved genetics (Mujica, 2005). Both breeds have followed adaptation and selection processes, but the characteristics of the founder effect of each one, the continuity or not of the genetic flow and the management of the gene pool are dissimilar and, to a certain extent, unknown. However, both breeds are part of the same animal population, where, although some breeders maintain processes of selection and conservation of the racial standard, the vast majority of productive livestock is managed under a confusing identification with one or both breeds generating different crossbreeding degrees between them (González et al., 2002; Dumenes et al., 2011), and also with minor contributions from third racial populations. This is confirmed deepening on the genetic structure of both breeds, where a great proximity in their genetic structure is observed (they cannot be clearly differentiated from each other) in comparison to the other racial populations present in the south of Chile (Piñeira et al., 2011).

Regarding to animal selection, it is necessary to consider that, in the absence of other means of selection, the animal morphostructure is an essential visual characteristic to differentiate and select animal biotypes, since it allows projecting the distinctive attributes of the corporality from an animal population to its offspring using such phenotypic criteria (Sierra, 2001; Holgado et al., 2015; Zhicay Orellana). In fact, it is the most used characterization applied by farmers, because the selection is made not only in consideration of the ranking of individual milk production. Many aspects of management and use influence the prioritization of certain body dimensions when choosing the breeding animals (Ballent et al., 2003; Chirinos; Holgado et al.; Riofrio, 2013).

For this reason, it is interesting to consider the body architecture as a result of the intention of livestock managing, which responds to a pattern of selection which is complementary to productivity, and which is expressed in the conformation of bovine biotypes with certain general characteristics, beyond the architecture of each separate breed (Ramónez Cárdenas et al, 2017). Thus, the objective of this work was to characterize the morphostructural architecture of bovine biotypes that are used mostly in milk production in southern Chile.

\section{MATERIAL AND METHOD}

Measurements were carried out in 26 dairy farms located in the provinces of Osorno and Ranco, in the Los Lagos and Los Ríos regions, respectively. In each farm, four animals were randomly selected from the herd; 104 four yearold cows were measured. Cows were classified into four biotypes (for each of the two breeds, farmers declared to have "pure" or "hybrid" cows): Holstein Friesian (HD), Overo Negro (OD), hybrid Friesian Holstein (HM) and hybrid Overo Negro (OM), according to the opinion of the owner or administrator. Nine body measurements were taken: head length (HL), head width (HW), withers height (WH), rump height (RH), bicostal diameter (BD), longitudinal diameter (LD), rump width (RW), rump length (RL) and dorso-sternal diameter (DED). Data were analyzed by principal component analysis (PCA) and the Fisher LSD test, using the XLstat pro program.

\section{RESULTS AND DISCUSSION}

Three factorial associations of variables that explain $63.97 \%$ of the total variability of the data were established (Fig. 1). The first association was BD, RL and HW; the second was DED, LD and RW; and the third was HL, RH and WH. The Y axis represented only $15.48 \%$ of the total variability; therefore, the differences or coincidences in that dimension are less relevant.

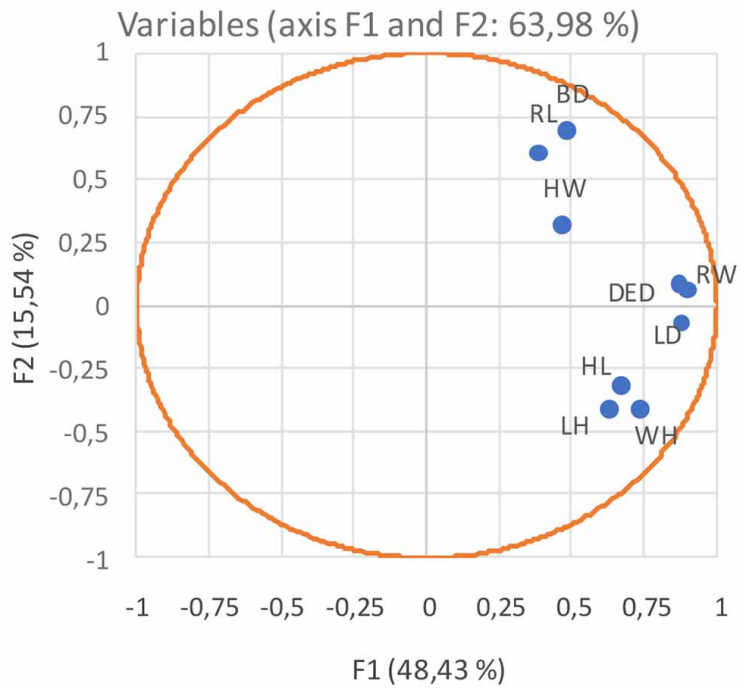

Fig. 1. Factorial plane representation of the variability of the morpho-structural measurements of bovine biotypes according to main components. Variables: head length (HL), head width (HW), withers height (WH), rump height (RH), bicostal diameter (BD), longitudinal diameter (LD), rump width (RW), rump length (RL) and dorso-sternal diameter (DED). 
The $\mathrm{X}$ axis describes $48.43 \%$ of the total variability; therefore, in this dimension the differences of the groups furthest apart are relevant. Thus, there was a greater differentiating power in the groups of variables BD, RL and HW compared to DED, LD and RW. This last association of variables is interesting since in the literature, the dimensions of depth (DED) and length (LD) are related to butcher performance, and the rump width (RW) to milk production (Shanks \& Spahr, 1982; Sieber et al., 1988; Valencia et al., 2008). The height, length, depth or rump width can be aspects considered by many farmers when choosing the replacement heifers (Piccardi et al., 2012, Riofrio), considering that, in addition to be more productive, they must efficiently move through heterogeneous grazing areas and, at the same time, be easy for milking or handling. This often determines the choice of a smaller animal, and thus the selection decision is not only based on the milk or meat yield ranking place. Several authors agree that biological functionality is conditioned by the underlying form of the animal biotype (Ballent, et al.; Toro et al., 2010; Chirinos; Holgado et al.). In this sense, biotypes should be differentiated according to their productive purpose. Holstein Friesian corresponds to a milk production purposed breed, while Overo Negro is a dual-purposed (milk-meat breed). It is expected that the biotypes will clearly differentiate according to these characteristics.
However, no significant differences were observed between biotypes in RW or DED (Table I). In LD, WH and $\mathrm{RH}$, there are subtle differences where Holstein Friesian tended to show slightly higher values. This result is striking, since the description of breeds related to these biotypes shows Holstein Friesian as a significantly higher and longer breed than Overo Negro (Shanks \& Spahr; Sieber et al.; Valencia et al.; Zhicay Orellana). Also based on the racial description, Holstein Friesian would be expected to have a greater rump width and a lower depth than the double purpose biotype. It should be considered that the qualification of the biotype is less rigorous than an official affiliation to a breed or genealogical register, and also that the degree of knowledge of the farmer about the breed standards can be approximate. However, dairy biotypes are managed and selected according to these definitions, and what is found is the result of this process.

It should be noted that the declared Holstein Friesian (HD) was found to be $134.9 \mathrm{~cm}$ of $\mathrm{WH}$, a low value compared to the international standard of the breed (Shanks \& Spahr; Sieber et al.; Valencia et al.) which is $142 \mathrm{~cm}$. However, this value is similar to those found in animals with a certain level of hybridization (Zhicay Orellana; Ramónez Cárdenas et al.). In this sense, it is plausible that the dairy biotypes move away from the specific racial

Table I. Mean values and standard deviation in body measurements in bovine biotypes.

\begin{tabular}{lcccccccc}
\hline & \multicolumn{2}{c}{ HD } & \multicolumn{2}{c}{ HM } & \multicolumn{2}{c}{ OD } & \multicolumn{2}{c}{ OM } \\
\multicolumn{1}{c}{ Variable } & Media $(\mathrm{cm})$ & s.d. & Media $(\mathrm{cm})$ & s.d. & Media (cm) & s.d. & Media $(\mathrm{cm})$ & s.d. \\
\hline HL & $57.4^{\mathrm{a}}$ & 2.59 & $56.3^{\mathrm{a}}$ & 2.49 & $56.9^{\mathrm{a}}$ & 3.31 & $56.8^{\mathrm{a}}$ & 2.17 \\
HW & $21.0^{\mathrm{a}}$ & 1.27 & $21.1^{\mathrm{a}}$ & 1.63 & $20.8^{\mathrm{a}}$ & 1.06 & $20.8^{\mathrm{a}}$ & 1.20 \\
WH & $134.9 \mathrm{a}$ & 3.20 & $132.8^{\mathrm{b}}$ & 3.84 & $133.4 \mathrm{~b}$ & 5.03 & $132.7 \mathrm{~b}$ & 3.76 \\
RH & $135.7^{\mathrm{a}}$ & 3.60 & $134.7 \mathrm{~b}$ & 4.43 & $134.1 \mathrm{~b}$ & 5.17 & $134.0 \mathrm{~b}$ & 4.76 \\
BD & $43.5^{\mathrm{a}}$ & 3.60 & $44.3^{\mathrm{a}} \mathrm{b}$ & 3.69 & $43.7^{\mathrm{a}} \mathrm{b}$ & 3.87 & $45.9^{\mathrm{c}}$ & 4.80 \\
LD & $159.5 \mathrm{a}$ & 8.34 & $155.9^{\mathrm{b}}$ & 8.70 & $156.7^{\mathrm{a}} \mathrm{b}$ & 11.18 & $156.6^{\mathrm{a}} \mathrm{b}$ & 7.53 \\
RW & $62.6^{\mathrm{a}}$ & 3.67 & $61.2^{\mathrm{a}}$ & 2.67 & $61.3^{\mathrm{a}}$ & 3.96 & $61.3^{\mathrm{a}}$ & 2.76 \\
RL & $27.8^{\mathrm{a}}$ & 2.41 & $28.4 \mathrm{~b}$ & 2.63 & $27.8^{\mathrm{a}}$ & 2.92 & $27.4^{\mathrm{a}}$ & 2.46 \\
DED & $73.0^{\mathrm{a}}$ & 3.11 & $72.9^{\mathrm{a}}$ & 3.37 & $72.5^{\mathrm{a}}$ & 5.09 & $72.5^{\mathrm{a}}$ & 3.17 \\
\hline
\end{tabular}

Within the same row, different letters indicate significant differences $(\mathrm{P}<0.05)$

Table II. Pearson correlation matrix of morphostructural measurements in bovine biotypes.

\begin{tabular}{llllllllll}
\hline Variable & HL & HW & WH & RH & BD & LD & RW & RL & DED \\
\hline HL & $\mathbf{1}$ & $\mathbf{0 . 2 3 8}$ & $\mathbf{0 . 4 9 7}$ & $\mathbf{0 . 3 4 3}$ & 0.107 & $\mathbf{0 . 5 7 8}$ & $\mathbf{0 . 5 6 6}$ & 0.053 & $\mathbf{0 . 5 6 0}$ \\
HW & $\mathbf{0 . 2 3 8}$ & $\mathbf{1}$ & $\mathbf{0 . 1 7 3}$ & 0.057 & $\mathbf{0 . 2 4 7}$ & $\mathbf{0 . 3 7 3}$ & $\mathbf{0 . 5 0 4}$ & 0.151 & $\mathbf{0 . 3 4 8}$ \\
WH & $\mathbf{0 . 4 9 7}$ & $\mathbf{0 . 1 7 3}$ & $\mathbf{1}$ & $\mathbf{0 . 7 1 6}$ & 0.099 & $\mathbf{0 . 5 7 5}$ & $\mathbf{0 . 5 0 9}$ & $\mathbf{0 . 2 1 2}$ & $\mathbf{0 . 5 8 6}$ \\
RH & $\mathbf{0 . 3 4 3}$ & 0.057 & $\mathbf{0 . 7 1 6}$ & $\mathbf{1}$ & 0.160 & $\mathbf{0 . 4 6 6}$ & $\mathbf{0 . 3 9 3}$ & 0.140 & $\mathbf{0 . 5 0 6}$ \\
BD & 0.107 & $\mathbf{0 . 2 4 7}$ & 0.099 & 0.160 & $\mathbf{1}$ & $\mathbf{0 . 3 2 5}$ & $\mathbf{0 . 4 2 9}$ & $\mathbf{0 . 4 8 7}$ & $\mathbf{0 . 4 7 8}$ \\
LD & $\mathbf{0 . 5 7 8}$ & $\mathbf{0 . 3 7 3}$ & $\mathbf{0 . 5 7 5}$ & $\mathbf{0 . 4 6 6}$ & $\mathbf{0 . 3 2 5}$ & $\mathbf{1}$ & $\mathbf{0 . 7 7 1}$ & $\mathbf{0 . 2 3 2}$ & $\mathbf{0 . 8 1 3}$ \\
RW & $\mathbf{0 . 5 6 6}$ & $\mathbf{0 . 5 0 4}$ & $\mathbf{0 . 5 0 9}$ & $\mathbf{0 . 3 9 3}$ & $\mathbf{0 . 4 2 9}$ & $\mathbf{0 . 7 7 1}$ & $\mathbf{1}$ & $\mathbf{0 . 2 2 9}$ & $\mathbf{0 . 7 6 0}$ \\
RL & 0.053 & 0.151 & $\mathbf{0 . 2 1 2}$ & 0.140 & $\mathbf{0 . 4 8 7}$ & $\mathbf{0 . 2 3 2}$ & $\mathbf{0 . 2 2 9}$ & $\mathbf{1}$ & $\mathbf{0 . 3 6 3}$ \\
DED & $\mathbf{0 . 5 6 0}$ & $\mathbf{0 . 3 4 8}$ & $\mathbf{0 . 5 8 6}$ & $\mathbf{0 . 5 0 6}$ & $\mathbf{0 . 4 7 8}$ & $\mathbf{0 . 8 1 3}$ & $\mathbf{0 . 7 6 0}$ & $\mathbf{0 . 3 6 3}$ & $\mathbf{1}$ \\
\hline
\end{tabular}

Bold values are different from 0 with an alpha significance value $=0.1$ 
standards, and converge around a pattern of cultural selection typical of the grazing systems of southern Chile, and circumscribed to selection aspects additional to production- related ones (Chirinos).

In this regard, it can be seen that DED, RW and LD show significant correlations with all the other measures, and are mostly above $50 \%$ (Table II), which reveals its incidence within a common selection pattern in the evaluated animals, where these dimensions are relevant.

It is interesting to consider that $\mathrm{RW}$ is a recognized measure in several studies since it is strongly correlated with milk production (Shanks \& Spahr; Sieber et al.; Valencia et al. al.). In addition, it is correlated with length (LD) and depth (DED) suggesting the existence of a basic architecture or shape of the animals selected to milk production in grazing systems (Chirinos; Riofrio). In this sense, if the differences between biotypes are subtle or nonexistent, other types of groupings of the animals given by the corporal dimensions can be searched for, beyond the biotypes that compose them. Figure 2 shows the grouping of the animals according to the criterion of dissimilarity, where three clusters $(\mathrm{C} 1, \mathrm{C} 2$ and $\mathrm{C} 3)$ were constituted.

When comparing the averages of the body measurements in the defined groups according to dissimilarity criteria, it can be seen that $\mathrm{C} 1$ tends to differ slightly from $\mathrm{C} 2$ and $\mathrm{C} 3$. The first cluster (C1) showed a shorter head (HW), lower elevations (WH and RH), shorter length (LD), smaller rump width (RW) and lower depth (DED), i.e., a small dairy cow biotype.

The first cluster (C1) grouped 31 animals, $\mathrm{C} 2$ to 14 and $\mathrm{C} 3$ to 59 individuals (Table III). Both in $\mathrm{C} 2$ and $\mathrm{C} 3$ larger dimensions in these body measurements where

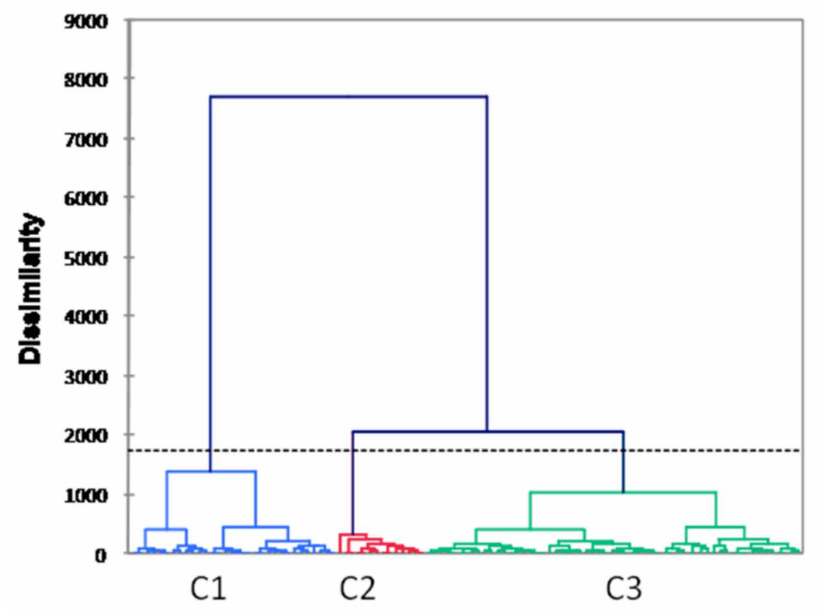

Fig. 2. Clusters according to criteria of dissimilarity of the morphostructural architecture in the bovine biotypes evaluated.

found; however, they did not show large differences between them. In this sense, it can be seen that within the evaluated animal group two selection patterns coexist. The first, represented by a small body architecture (Cluster C1), which included approximately one third of the evaluated animals (31), and another represented by clusters $C 2$ and C3, with 14 and 59 animals respectively, which exhibited larger dimensions, but in turn represents a small dairy animal compared to the dimensions described in official Holstein Friesian records and reached in other areas (Chirinos; Riofrio; Zhicay Orellana).

When analyzing the percentages of each biotype present in each cluster, it can be seen that in cluster $\mathrm{C} 1$, which corresponds to the body architecture of the smallest animals, the four biotypes analyzed participate, with a similar frequency of participation between HD and OM, and between HM and DO, even though both pairs of biotypes show significant differences between them (Table IV).

Table III. Average standard of body measurements in the groupings defined according to criteria of dissimilarity of the morphostructural architecture.

\begin{tabular}{|c|c|c|c|c|c|c|c|c|c|}
\hline \multirow{3}{*}{ Variable } & \multicolumn{9}{|c|}{ Cluster } \\
\hline & \multicolumn{3}{|c|}{$\mathrm{C} 1$} & \multicolumn{3}{|c|}{$\mathrm{C} 2$} & \multicolumn{3}{|c|}{$\mathrm{C} 3$} \\
\hline & MEDIA & MAX & MIN & MEDIA & MAX & MIN & MEDIA & MAX & MIN \\
\hline HL & $53.1^{\mathrm{a}}$ & 58 & 52 & $58.19^{b}$ & 63 & 43 & $60.14 \mathrm{~b}$ & 63 & 57 \\
\hline HW & $19.69^{a}$ & 21.5 & 18 & $21.48^{a}$ & 27 & 19 & $21.46^{\mathrm{a}}$ & 23 & 20 \\
\hline WH & $126.35^{\mathrm{a}}$ & 137 & 124 & $136.52^{b}$ & 144 & 128.5 & $137.61 \mathrm{~b}$ & 145 & 133 \\
\hline $\mathrm{RH}$ & $127.84^{\mathrm{a}}$ & 138.5 & 123 & $138.03^{b}$ & 144 & 129.5 & $136.21 \mathrm{~b}$ & 140.5 & 130.5 \\
\hline $\mathrm{BD}$ & $40.48^{\mathrm{a}}$ & 48 & 37 & $46.34^{\mathrm{b}}$ & 53 & 37 & $44.00 \mathrm{c}$ & 49 & 40 \\
\hline LD & $142.45^{\mathrm{a}}$ & 158 & 137.5 & $161.98^{b}$ & 164 & 137.5 & $171.29 \mathrm{~b}$ & 178 & 164 \\
\hline RW & $56.15^{\mathrm{a}}$ & 61 & 53.5 & $63.84^{\mathrm{b}}$ & 67 & 53.5 & $65.36 \mathrm{~b}$ & 70 & 61.5 \\
\hline $\mathrm{RL}$ & $25.77^{\mathrm{a}}$ & 30 & 20.5 & $29.26^{\mathrm{b}}$ & 32 & 20.5 & $26.79^{a}$ & 31 & 21 \\
\hline DED & $66.63^{a}$ & 72 & 62 & $74.9^{\mathrm{b}}$ & 77 & 70 & $77.5 \mathrm{~b}$ & 80 & 74 \\
\hline
\end{tabular}

Within the same row, different letters indicate significant differences $(\mathrm{P}<0.05)$ 
Table IV. Frequency of correspondence of bovine biotypes with the clusters defined according to criteria of dissimilarity of the morphostructural architecture

\begin{tabular}{cccrrrr}
\hline Cluster & $\begin{array}{c}\text { Number of } \\
\text { observations }\end{array}$ & HD (\%) & HM (\%) & OD (\%) & OM (\%) & Total \\
\hline C1 & 31 & $32.20^{\mathrm{a}}$ & $19.40 \mathrm{~b}$ & $19.40^{\mathrm{b}}$ & $29.00^{\mathrm{a}}$ & 100 \\
$\mathrm{C} 2$ & 14 & $50.00^{\mathrm{a}}$ & $14.30 \mathrm{c}$ & $28.60^{\mathrm{b}}$ & $7.10^{\mathrm{c}}$ & 100 \\
$\mathrm{C} 3$ & 59 & $25.50^{\mathrm{a}}$ & $22.0 \mathrm{~b}^{\mathrm{c}}$ & $32.20^{\mathrm{a}}$ & $20.30^{\mathrm{c}}$ & 100 \\
\hline
\end{tabular}

In cluster $\mathrm{C} 2$, the Holstein Friesian biotype, both declared pure and hybrid, reached a frequency of $64.3 \%$ while in $\mathrm{C} 3$ the frequency was less than $50 \%$. This implies that the greater body span shown by the $\mathrm{C} 2$ and $\mathrm{C} 3$ clusters would not be explained by the frequency of biotypes related to the Holstein Friesian breed. In this sense, the data indicate that the body architecture of the dairy cattle evaluated would respond to selection patterns more than to the reference racial biotypes.

\section{CONCLUSIONS}

According to the results, it can be concluded that, under the conditions of the present study, the evaluated animals seem to converge around a basic architecture derived from cultural selection patterns regardless of the racial biotype. This architecture could be typical of grazing systems, or be influenced by aspects of phenotypic selection additional to those directly related to production traits. The data show that the body architecture of the dairy cattle evaluated would respond to selection patterns more than to racial biotypes. It was also seen that measures such as DED, RW and LD had a greater incidence than the other variables within the observed common selection patterns. Finally, within the evaluated animal population, two selection patterns coexist, one represented by small size body architecture and another one that, although despite its larger dimensions, also represents a small dairy animal in comparison to the sizes reported for Holstein Friesian breed in other areas.

\section{ACKNOWLEDGMENTS}

The authors wish to thank Mr. Paulo Guarda for his support in the animal measurements. Founding for this study was given by the Regional Government of Los Lagos in through the Capacitación y valorización de productos agropecuarios Program, and World Organization for Food and Agriculture (FAO) through the project in situ conservation strategies for cattle and goats.
DE LA BARRA, R.; CARVAJAL, A. M.; MARTÍNEZ, M. E. \& MORALES, R. Arquitectura corporal de biotipos bovinos Holstein Friesian y overo negro utilizados en predios lecheros del sur de Chile. Int. J. Morphol., 37(4):1444-1449, 2019.

RESUMEN: El objetivo de este trabajo fue caracterizar la arquitectura morfoestructural de los biotipos bovinos que mayoritariamente se utilizan en la producción de leche en el sur de Chile. Para ello se realizaron evaluaciones en 26 predios lecheros ubicados en las provincias de Osorno y Ranco, en las regiones de Los Lagos y Los Ríos, respectivamente. Se midieron 104 animales clasificados en cuatro biotipos según lo declarado por los ganaderos: Holstein Friesian (HD), Overo negro (OD) y cruzamientos de Holstein Friesian (HM) y Overo Negro (OM). En cada animal se determinaron nueve medidas corporales: longitud de la cabeza (HL), ancho de la cabeza (HW), alzada a la cruz (WH), alzada a la grupa (RH), diámetro bicostal (BD), diámetro longitudinal (LD), ancho de la grupa (RW), longitud de la grupa (RL) y diámetro dorso-esternal (DED). Los datos se analizaron mediante análisis de componentes principales (PCA) y el test de Fischer LSD, usando para ello el programa XLstat pro. De acuerdo a los resultados se puede concluir que, independiente del biotipo racial, los animales evaluados parecen converger en torno a una arquitectura básica derivada de patrones de selección fenotípica con un componente cultural que pudiera ser propia de los sistemas de pastoreo, o influenciada por aspectos de selección adicionales a los relacionados directamente a la producción. En este sentido, los datos indican que la arquitectura corporal del ganado lechero respondería más a patrones de selección que a biotipos raciales. También se apreció que la profundidad (DED), el ancho de grupa (RW) y el largo (LD) presentan una mayor incidencia que las demás variables evaluadas dentro de los patrones de selección común observados. Finalmente, fue posible apreciar que al interior de la población animal evaluada coexisten dos patrones de selección. Uno representado por una arquitectura corporal de pequeño tamaño y otro que, si bien exhibe mayores dimensiones, también representa un tipo de animal lechero de menor tamaño en comparación a las dimensiones que alcanzan los biotipos relacionados a la raza Holstein Friesian en otras zonas.

PALABRAS CLAVE: Morfología; Ganado; Características poblacionales; Etnología.

\section{REFERENCES}

Anrique, R.; Latrille, L.; Balochi, O.; Alomar, D.; Moreira, V.; Smith, R. \& Vargas, G. La producción de leche en Chile: Caracterización técnica a nivel predial. Valdivia, Universidad Austral de Chile, Facultad de Ciencias Agrarias, 2004. 
Ballent, M.; Landi, H. G.; Bilbao, G. \& Dick, A. Pubertad, peso vivo y desarrollo corporal en diferentes biotipos bovinos productores de leche: una actualización bibliográfica. ITEA, 99(2):130-8, 2003.

Campos, P. J.; De Pedro Sanz, E.; Williams, S. P.; Basso, B. I.; Herrera, C. O.; Iturriaga, A. D. \& Bórquez, L. F. Carne bovina Chilena potencialmente exportable al mercado surcoreano proveniente de novillos de la zona centro-sur de Chile. Agro-Ciencia Chil. J. Agric. Anim. Sci., 28(1):51-61, 2012.

Chirinos, Z. La Funcionalidad Animal, Herramienta Esencial para el Mejoramiento del Rebaño Bovino. Zulia, Universidad del Zulia, Facultad de Agronomía, 2011.

Corporación de Fomento de la Producción. Geografía Económica de Chile. Tomo III. Santiago de Chile, Corporación de Fomento de la Producción, Fundación Pedro Aguirre Cerda, 1962.

Correa, L. La Agricultura Chilena. Tomo II. Santiago de Chile, Imprenta Nascimiento, 1938.

Dumenes, O. K.; Mujica, C. F. \& Uribe, M. H. Efecto de la edad al primer parto sobre rendimientos productivos y reproductivos de un rebaño lechero de la Región de los Ríos. Agro Sur, 39(3):125-32, 2011.

González, H.; García, X.; Magofke, J. C. \& Cuevas, A. Comparación de diferentes cruzamientos entre frisón negro chileno con frisón neozelandés y con holstein americano. Arch. Zootec., 51(195):303-14, 2002.

Holgado, F. D.; Ortega, M. F. \& Fernández, J. Evolución, con la edad, de diferentes medidas corporales en hembras bovinas de la raza Criollo Argentino. Actas Iberoam. Conserv. Anim., 2015:178-183, 2015.

Matthei, A. La Agricultura en Chile y la Política Agraria Chilena. Santiago de Chile, Imprenta Nacimiento. 1939.

Mc Parland, S.; Kearney, J. F.; Rath, M. \& Berry, D. P. Inbreeding effects on milk production, calving performance, fertility, and conformation in Irish Holstein-Friesians. J. Dairy Sci., 90(9):4411-9, 2007.

Mujica, F. Diversidad, conservación y utilización de los Recursos Genéticos Animales en Chile. Osorno, Boletín INIA No.137, 2005.

Notter, D. R. The importance of genetic diversity in livestock populations of the future. J. Anim. Sci., 77(1):61-9, 1999.

Peralta, G. Historia Económica y Urbana de Osorno. Santiago de Chile, Impresur Ltda., 1991.

Piccardi, M.; Balzarini, M.; Bó, G. \& Capitaine, A. Morphological traits and the association with milk production in Holstein cows. Rev. Vet., 23(2):134-7, 2012

Piñeira, V. J.; Mujica, C. F.; Felmer, D. R.; Ortiz, L. M.; Pizarro, I. G. \& Aracena, N. M. Caracterización genética de un rebaño de bovino criollo patagónico chileno. Agro Sur, 39(1):46-56, 2011.

Ramónez Cárdenas, M. A. \& Zhunio Samaniego, L. E. Caracterización Morfométrica e Índices Zoométricos de los Grupos Raciales Bovinos Existentes en los Cantones Occidentales de la Provincia del Azuay. Bachelor's Thesis. Cuenca, Universidad de Cuenca, Facultad de Ciencias Agropecuarias, Carrera de Medicina Veterinaria y Zootecnia, 2017. Available from: http://dspace.ucuenca.edu.ec/bitstream/123456789/ 28336/1/Trabajo \%20de \%20titulaci \%C3 \%B3n.pdf

Riofrio, L. A. Características a seleccionar en bovinos tipo leche para las ganaderías de la Región Sur del Ecuador. Centro de Biotecnología, 2(1):59-67, 2013.

Salinas, J. Caracterización Morfométrica de la Población Bovina Adaptada a las Condiciones Ambientales, en la Parroquia Zurmi, del Cantón Guaizimi, Provincia de Zamora Chinchipe. Tesis de título de Médico Veterinario Zootecnista. Loja, Universidad Nacional de Loja, Facultad Agropecuaria y de Recursos Naturales Renovables, 2017. Available from: http://dspace.unl.edu.ec/jspui/bitstream/123456789/19224/1/Jos \%C3 \%A9 \%20Miguel \%20Salinas \%20Salinas.pdf

Shanks, R. D. \& Spahr, S. L. Relationships among udder depth, hip height, hip width, and daily milk production in Holstein cows. J. Dairy Sci., 65(9): 1771-5, 1982.

Sieber, M.; Freeman, A. E. \& Kelley, D. H. Relationships between body measurements, body weight, and productivity in Holstein dairy cows. J. Dairy Sci., 71(12):3437-45, 1988.
Sierra, I. El concepto de raza: evolución y realidad. Arch. Zootec., 50:54764, 2001.

Toro, I. M. V.; Manríquez, S. G. \& Suazo, G. I. Geometric morphometry and the biologic shapes study: from the descriptive morphology to the quantitative morphology. Int. J. Morphol., 28(4):977-90, 2010.

Valencia, P. M.; Montalbo, V. H. \& Ruiz, L. F. Parámetros genéticos para características de conformación, habilidad de permanencia y producción de leche en ganado Holstein en México. Tec. Реси. Mex., 46(3):23548, 2008.

Vergara, C. Cálculo de Consanguinidad en un Rebaño Lechero Doble Propósito (Overo Colorado) y su Relación con Niveles Productivos y Reproductivos. Tesis de Grado de Licenciado en Agronomía. Valdivia, Universidad Austral de Chile, Facultad de Ciencias Agrarias, 2002. Available from: http://cybertesis.uach.cl/tesis/uach/2002/fav494c/doc/ fav494c.pdf

Zhicay Orellana, W. O. Valoración de Rasgos Morfométricos y Productivos de Vacas Holstein Mestizo y Puras en el Cantón Chambo. Tesis de Título de Ingeniero Zootecnista. Chimborazo, Escuela Politécnica Superior de Chimborazo, Facultad de Ciencias Pecuarias, 2016. Available from: http://dspace.espoch.edu.ec/bitstream/123456789/5384/1/ 17T1414.pdf

\section{Corresponding author:}

Maria Eugenia Martínez

Instituto de Investigaciones Agropecuarias, INIA

Butalcura

CHILE

Email: eugemartinez.inia@gmail.com

Received: 03-10-2018

Accepted: 10-06-2019 